\title{
PENGARUH STRUKTUR KEPEMILIKAN, EFEKTIVITAS KOMITE AUDIT, DAN KUALITAS AUDIT TERHADAP LUAS PENGUNGKAPAN KOMPENSASI MANAJEMEN KUNCI DALAM LAPORAN KEUANGAN (STUDI EMPIRIS PADA PERUSAHAAN SEKTOR PERDAGANGAN YANG TERDAFTAR DI BURSA EFEK INDONESIA PERIODE 2015 S.D. 2017)
}

\author{
Muhammad Fazil $^{* 1}$, Nadirsyah ${ }^{* 2}$ \\ 1,2Program Studi Akuntansi Fakultas Ekonomi dan Bisnis Universitas Syiah Kuala \\ e-mail: fazil.mhs@ unsyiah.ac.id ${ }^{* 1}$, nadirsyah@ unsyiah.ac.id ${ }^{* 2}$
}

\begin{abstract}
This study aims to investigate the effect of institutional ownership, managerial ownership, audit committee effectiveness, and audit quality both simultaneously and partially on the disclosures of key management compensation in financial statements. The test employed in this research is hypotheses while the data applied is secondary in the form of company financial and annual reports obtained from the official website of the Indonesia Stock Exchange and the official pages of each company that is analyzed using multiple linear regression analysis. The sampling method used is purposive sampling method with population of 61 companies listed in Indonesian Stock Exchange for the period 2015 until 2017 and sample of 41 companies. The results of this study indicate that institutional ownership, managerial ownership, audit committee effectiveness, and audit quality simultaneously have a significant and positive effect on the disclosures of key management compensation in financial statements. Furthermore, institutional ownership, audit committee effectiveness, and audit quality partially have a significant and positive effect for the disclosure of key management compensation, while managerial ownership partially does not have a significant effect on the disclosures of key management compensation in financial statements.
\end{abstract}

Keywords: Disclosure of Key Management Compensation, Institutional Ownership, Managerial Ownership, Audit Committee Effectiveness, and Audit Quality

\section{Pendahuluan}

Laporan keuangan pada dasarnya ialah suatu cara manajemen bertanggung jawab kepada pemegang saham. Hal itu dilakukan karena pihak manajemen telah dipercaya oleh pemegang saham untuk mengelola entitas. "Laporan keuangan tersebut diharapkan dapat memberikan informasi-informasi yang dapat digunakan oleh stakeholders (pihak-pihak yang berkepentingan) dalam pengambilan keputusan" (SFAC No.1, 2008). Oleh karena itu, setiap entitas dituntut untuk menyusun dan menyajikan laporan keuangan sesuai dengan SAK (Standar Akuntansi Keuangan) yang berlaku. Stakeholders akan terbantu dalam pengambilan keputusan seandainya perusahaan melakukan pengungkapan terhadap informasi keuangan perusahaan yang bersifat material.

Jenis pengungkapan (disclosure) terbagi dua, yaitu "pengungkapan wajib (mandatory disclosure) dan pengungkapan sukarela (voluntary disclosure). pengungkapan wajib adalah pengungkapan yang diwajibkan oleh peraturan pemerintah, sedangkan pengungkapan sukarela adalah pengungkapan yang tidak diwajibkan oleh peraturan pemerintah" (Naim \& Rakhman, 2000). Salah satu komponen informasi dalam pengungkapan wajib adalah pemyajian pihakpihak punya hubungan.

Menurut PSAK No.7 Pengunggkapan pihakpihak berelasi merupakan pengungkapan yang wajib dilakukan perusahaan berkaitan dengan adanya hubungan dengan pihak-pihak berelasi (IAI, 2018). Penyajian ini diregulasikan pada PSAK No. 7. PSAK ini khusus membahas pengungkapan-pengungkapan berkaitan dengan transaksi pihak berelasi yang wajib dilaporkan oleh entitas dalam laporan keuangannya.

Saat ini, terdapat perhatian yang sangat serius terhadap transaksi antara pihak-pihak berelasi oleh beberapa pihak, baik mereka yang terlibat dalam dunia bisnis maupun pemerintah. Menurut PSAK No.7 menyatakan hal ini terjadi karena pihak-pihak yang memiliki relasi bisa mengerjakan kegiatan kegiatan 
yang belum tentu bisa dilakuka oleh pihak lain (IAI, 2018). Kondisi tersebut tentunya akan berimbas pada keuntungan maupun kerugian bagi stakeholders dalam pengambilan keputusan. Oleh karena itu, pihak-pihak berkepentingan berhak untuk mendapatkan informasi yang transparan dan lengkap berkaitan dengan transaksi yang terjadi antara pihak-pihak berelasi.

Akibat yang mungkin akan terjadi disebabkan adanya transaksi antara pihak-pihak berelasi, maka DSAK merumuskan PSAK No.. 7. Salah satu bagian yang diwajibkan pengungkapan oleh PSAK No. 7 adalah pengungkapan informasi tentang pembayaran kompensasi kepada manajemen kunci. Adapun kompensasi yang wajib diungkapkan perusahaan yaitu: "(i) imbalan kerja untuk jangka pendek, (ii) imbalan

Tabel 1.1

Luas pengungkapan Kompensasi Manajemen Kunci dalam laporan keuangan Perusahaan Sektor Perdagangan Tahun 2017

\begin{tabular}{|l|c|c|}
\hline \multicolumn{1}{|c|}{ Pengungkapan } & $\begin{array}{c}\text { Jumlah } \\
\text { Perusahaan }\end{array}$ & \% \\
\hline Tidak mengungkapkan kompensasi manajemen kunci dalam laporan keuangan. & 3 & $10 \%$ \\
\hline Mengungkapkan total kompensasi tanpa keterangan kategori imbalan. & 11 & $37 \%$ \\
\hline Mengungkapkan total kompensasi masing-masing komisaris dan direksi. & 3 & $10 \%$ \\
\hline Mengungkapkan total kompensasi dengan memberikan deskripsi/kategori imbalan. & 4 & $13 \%$ \\
\hline $\begin{array}{l}\text { Mengungkapkan total kompensasi dan memberikan rincian subjumlah perkategori imbalan } \\
\text { kerja. }\end{array}$ & 9 & $30 \%$ \\
\hline Total & 30 & $100 \%$ \\
\hline
\end{tabular}

Sumber: Observasi awal (2019)

Berdasarkan tabel 1,1 tersebut, pengungkapan kompensasi manajemen kunci perusahaan sektor perdagangan untuk tahun 2017 hanya sebesar $30 \%$ (9 perusahaan) dari total 30 perusahaan yang memenuhi kewajiban PSAK No. 7. Perusahaan telah melakukan pengungkapan total kompensasi beserta rincian subjumlah perkategori imbalan kerja yang dibayarkan kepada manajemen kunci perusahaan. Sebesar 13\% (4 perusahaan) dari total 30 perusahaan yang melakukan pengungkapan semua kompensasi ditambah lagi dengan ilustrasi jenis imbalan, sebesar $10 \%$ (3 perusahaan) dari total 30 perusahaan yang melakukan pengungkapan total kompensasi masingmasing komisaris dan direksi, dan sebesar 37\% (11 perusahaan) dari total 30 perusahaan hanya menjadikan total kompensasi tanpa keterangan kategori imbalan, serta terdapat $10 \%$ ( 3 perusahaan) yang tidak melakukan pengungkapan sama sekali.

Selain itu, ketidakpatuhan enittas juga terjadi di sektor manufaktur. Di mana hanya sebesar 19,33\% (63 pascakerja, (iii) imbalan kerja jangka panjang lainnya, (iv) pesangon, dan (v) kompensasi berbasis saham “(IAI, 2018).

Perusahaan sektor perdagangan di Indonesia masih sangat rendah dalam menungkapan kompensasi yang dibayarkan kepada manajemen kunci. Hal ini sebagai mana temuan dari observasi awal peneliti terhadap 30 perusahaan sektor perdagangan yang sedang terdaftar di BEI tahun 2017, yang dijelaskan dalam Tabel 1.1 berikut: 
pengungkapan tersebut merupakan bagian dari upaya perusahaan untuk mengaplikasikan prinsip transparansi (transparancy). Sehingga dengan dilakukan pengungkapan tersebut dapat meningkatkan tata kelola perusahaan (Setyajati, 2015). Ketiga, informasi tersebut sangat diharapkan sekali oleh mereka yang dikenal sebagai stockholders saat mengambil keputusan. "Pemegang saham tidak dapat mengendalikan keputusan komisaris dalam pemberian kompensasi bagi manajemen kunci jika informasi mengenai kompensai manajemen kunci tidak lengkap dilaporkan di laporan keuangan " (Donahue, 2008).

Kompensasi yang dibayarkan kepada direktur dan komisaris juga merupakan transaksi yang mempunyai potensi munculnya morall hazardd pada manajemen perusahaan, akibatnya bisa memunculkan konflik keagenan (Akmyga \& Mita, 2015). "Konflik keagenan ini memungkinkan pihak manajemen untuk bertindak melanggar etika" (Fauziah, 2018). Sebagai pihak yang memahami bisnis secara utuh, manajemen akan bersikap oportunis, sehingga tidak menyajikan informasi secara luas dan lengkap pada pihak yang dikenal sebagi stockholders (Bhattacharya \& Spiegel, 1991).

Menurut riset terdahulu, ada beberapa faktor yang mempengaruhi LPKMK di laporan keuangan. Salah satu faktornya yakni struktur kepemilikan perusahaan. Struktur kepemilikan yang dipakai pada riset ini yaitu KI (kepemilikan Institusianal) dan KM (kepemilikan manejerial).

KI mempunyai posisi besar dalam meminimalkan masalah agensi yang muncul antara stockholders dengan manejer entitas. "Adanya kepemilikan institusional pada suatu perusahaan akan mendorong peningkatan pengawasan lebih optimal terhadap kinerja manajemen" (Astasari \& Nugrahanti, 2015). Dengan pengawasan yang baik dari pihak investor institusi, manajemen akan melakukan pengungkapan informasi yang diperlukan stockholders secara jelas. Hasil riset Chizema (2008) di Jerman menunjukkan KI punya berpengaruh secara tinggi dan sifat positif pada penyajian gaji direksi perusahaan.

Struktur kepemiliikan selanjutnya adalah KM. KM dipersepsikan dianggap bisa menyelesaikan konflik keaginan, akibat bisa menyelaraskan tujuan antara manajer dengan stockholders (Jensen \& Meckling, 1976). Baik manajer dan pemegang saham yang lain akan mendapatkan dampak yang sama jika perusahaan mendapatkan keuntungan maupun kerugian. KI " mampu mendorong manajemen untuk memberikan informasi yang bersifat wajib di laporan keuanganya dalam rangka menjaga reputasi perusahaan" (Akmyga \& Mita, 2015). Suherman (2018) menunjukkan bahwa KM mempunyaii pengaruh secara berarti pada LPKMK di laporan keuangan perusahaan.

Faktor yang lainnya adalah EKA. Menurut Zhang et, al. (2007) mengatakan efektivitas komite akan berbanding lurus dengan efektifnya pengendalian internal perusahaan. Efektifnya pengendalian internal perusahaan diharapkan dapat memacu perusahaan untuk patuh pada regulasi dan SAK. Utama (2004) juga mengatakan komiti audit bertugas secara bagusif akan memotivasi manejemen perusahaan menyajikan informasi yang material. Akmyga \& Mita (2015), dan Fauziah (2018) menemukan EKA mempengaruhi LPKMK dalam laporan keuangan.

Faktor yang lainnya adalah KA. Menurut Bassett et al. (2007) terdapat hubungan yang berbanding lurus diantara kuantitas audit dengan luas informasi financial yang diungkapkan oleh entitas. Semakin bagus KA, jadi semakin luas penyajian informasi yang dikerjakan suatu perusahaan. Sebaliknya, semakin kurang bagus KA suatu perusahaan, maka semakin kurang informasi yang diungkapkan oleh suatu perusahaan. (Farahmita, 2012; Akmyga \& Mita, 2015; Fauziah, 2018) menemukan KA mempunyai hubungan secara besar dan positif terhadap LPKMK dalam laporan keuangan.

Penelitian ini sebetulnya modifikasi studi-studi terdahulu tentang LPKMK dalam laporan keuangan. Berdasarkan studi sebelumnya, peneliti berkeinginan untuk melakukan pengembangan lebih lanjut terkait dengan penelitian tersebut. Terdapat perbedaan mendasar pada riset ini. Pada riset ini, peneliti meneliti perusahaan sektor perdagangan yang listing di BEI dari tahun 2015 s.d. 2017. Pemilihan perusahaan sektor perdagangan dilakukan untuk menjawab keterbatasan penelitian sebelumnya. Dilakukan penelitian dalam beberapa tahun dengan tujuan dapat memberikan hasil penelitian yang beragam serta dapat dibandingkan antar periode, sehingga penelitian ini lebih komparatif dibandingkan penelitian terdahulu. 


\section{Kerangka Teoritis Dan Pengembangan Hipotesis Teori Keagenan}

Teori keagenan meupakan sebuah teori yang memberikan ulasan mengenai terkait kontrakt antara principal dengan agent. "hubungan agensi muncul ketika principal mempekerjakan agent untuk memberikan suatu jasa dan kemudian mendelegesikan wewenang pengambilan keputusan kepada agent tersebut" (Jensen \& Meckling, 1976). Agent dapat didefinsikan semacam aktor yang mengatur entitass, seperti direktur perusahaan. Semacam ini agent bertindak sebagai pihak yang membuat keputusan dalam menjalankan perusahaan. Adapun principal didefinisikan sebagai pihak yang memberikan delegasi wewenang kepada pihak manajemen perusahaan, seperti pemegang saham.

Kedua belah pihak tersebut memiliki motivasi yang berbeda, dan masing-masing dari mereka akan mencoba untuk memenuhi kepentingan dirinya sendiri. Agent untuk memenuhi kebutuhan finansial dan kebutuhan jiwanya melalui berbabai cara seperti: investasi, kontrak kompensasi dan pinjaman, sedangkan principal termotivasi untuk terus meningkatkan profitabilitas perusahaan (Akmyga \& Mita, 2015). Perbedaan motivasi itulah yang memberikan celah munculnya konfilk keagenan. Untuk mencegah terjadinya kondisi tersebut, principal bisa mencegahnya dengan memberikan gaji sesuai pada agent dan mengerjakan pengawasan yang di desain untuk mengurangi kegiatan agent yang berlawanan dengan keinginan principal.

Pokok kegunaan teori ini yakni untuk memberikan ilustrasi tentang cara-cara pihak-pihak yang membuat kontrak dapat membuat kontrak yang dirancang untuk mengurangi biaya sebagai akibat dari informasi dan ketidakpastian yang asimetris. Dalam relasi keagenan, terdapat kontrak antara principal dengan agent. Agent sepakat dan semangat untuk membuat aktivitas tertentu bagi pemegang saham, dan principal akan memberikan gaji yang cukup pada agent. "Pembayaran kompensasi manajemen kunci tidak terlepas dari teori keagenan. Hal ini dikarenakan pembayaran kompensasi sebagai salah satu transaksi pihak-pihak berelasi memiliki potensi timbulnya moral hazard pada manajemen, sehingga dapat mengakibatkan munculnya konflik keagenan" (Akmyga \& Mita, 2015).
Direktur dan agen akan berusaha menjauhkan dampak konflik keagenan dengan mengorbankan serangkaian biaya yang dikenal pengeluaran agen."Apabila agent dan principal dapat bekerja sama dan tidak melakukan kecurangan, maka biaya keagenan dapat diminimalisir" (Akmyga \& Mita, 2015). Selain itu, konflik antar lembaga juga dapat diminimalisir melalui KM, KI, EKA, KA, yang dipercaya dapat meningkatkan kejalasan dan luasnya penyajian.

\section{Pengaruh KI Terhadap LPKMK dalam Laporan Keuangan}

KI merupakan "kepemilikan saham perusahaan oleh institusi keuangan, seperti perusahaan asuransi, bank, dana pensiun, dan investment banking" (Sirigar \& Utama, 2008). Menurut Pujiiningsih (2011) menyebutkan pihak institusiional merupakan pemegang saham yang memiliki pengalaman yang cukup bila dicoba bandingkan dengan pemegang saham individual (sophistical Investor). Hal ini dikarenakan KI dituntut untuk mempertanggunjawabkan setiap keputusan yang diambil pada berbagai pihak yang telah memberikan kepercayaan kepadanya.

KI mempunyai porsi yang besar dalam menyelesaikan masalah agensi yang tercipta diantara pihak stockholders dengan pihak manajemen perusahaan. "Adanya kepemilikan institusional pada suatu perusahaan akan mendorong peningkatan pengawasan terhadap kinerja manajemen" (Astasari \& Nugrahanti, 2015). Sehingga dapat mendesak pihak manajemen untuk tidak melakukan tindakan penyelewangan yang dapat menurunkan nilai perusahaan (Tamba, 2011).

Jika persentase KI, dapat membuat meningkatnya pengawasan pada manajemen untuk meningkatkan nilai perusahaan (Irfana \& Muid, 2012). Adanya pengawasan yang lebih baik pemegang saham institusional akan mendorong manajemen untuk melakukan pengungkapan info yang diperlukan stockholdeers secara jelas, salah satu info tersebut adalah gaji yang dibayarkan kepada manajemen kunci perusahaan.

"Adanya kepemilikan institusional akan mendorong peningkatan pengawasan yang lebih optimal yang diharapkan dapat mereduksi perilaku opportunistic para manajer, sehingga akan mendorong 
luasnya pengungkapan informasi dalam laporan keuangan" (Bangun et al., 2012). Penelitian Chizema (2008) menemukan KI institusi memiliki hubungan secara berarti terhadap penyajian gaji direktur. Hasil itu juga sama dengan temuan Mayresa (2018), menemukan bahwa KI mempunyai hubungan dengan LPKMK pada laporan.

\section{Pengaruh KM Terhadap LPKMK pada Laporan Keuangan}

KM merupakan kepemilikan saham perusahaan oleh direktur utama, manajemen ikut aktif saat mengambil kebijakan. KM tersebut dinilai "dapat mengatasi terjadinya konflik keagenan, karena dapat menyelaraskan kepentingan antara manajer dengan pemegang saham" (Jensen \& Meckling, 1976). kondisi ini dikarenakan manejemen juga ikut menerima kenikmatan langsung dari kebijakan yang diperbuat, dan akan pula menerima akibat atas kekeliruan kebijakan yang mereka perbuat. Menurut Tamba (2011) kekayaan manajemen juga semakin terikat dengan kekayaan perusahaan akibat adanya kepemilikan perusahaan. Oleh karena, manajemen akan terus berupaya untuk mengurangi risiko kehilangan kekayaannya.

Seandaianya tinggi KM, akan cukup berhatihati dan berupaya sebaik mungkin dalam mengambil keputusan perusahaan guna terpenuhinya tujuan stockhollders, yang masuk manajemen juga. selain itu, "kepemilikan manajerial salah satu proksi mekanisme tata kelola perusahaan yang dapat membantu mengurangi asimetris informasi dan mendorong perusahaan untuk mengungkapkan informasi secara tepat waktu" (Bhojraj \& Sengupta, 2003).

Dengan demikian, manejemen terus berupaya meningkatkan harga perusahaan guna memberikan kenyakinan kepada pihak luar untuk berinvestasi. Yaitu dengan dengan menyajikan remunerasi yang diberikan kepada direktur yang dipersepsikan bisa memberikan ilustrasi kepada pihak luar mengenai prospek entitas. Hal ini tidak terlepas dari pendapat (Conyon \& He, 2011) yang menyatakan bahwa remunerasi yang diberikan kepada direksi dan komisaris sesuai dengan prospek entitas.

KM memiliki kemampuan "mendorong manajemen untuk memberikan informasi yang bersifat wajib di laporan keuanganya dalam rangka menjaga reputasi perusahaan" (Akmyga \& Mita ,2015). Selain itu, Purwandari \& Purwanto (2012) menyebutkan KM mempunyai hubungan yang positif dengan Indeeks Wallaces salah satu yang termasuk dalam indek tersebut yaitu remunerasi direksi dan komisaris.

Morck \& Yeung (2003) menyatkan seadnainya persentase KM tinggi suatu entitas dapat memacu pihak manajerial meningkatkan luas penyajian remunerasi yang dikasih kepada manajemen kunci serta pengungkapan dilakukan dngan lebih jelas lagi. Hasil penelitian Suherman (2018) menemukan bahwa KM mempunyai hubungan yang berarti terhadap LPKMK pada laporan keuaangan perusahaan.

\section{Pengaruh EKA Terhadap LPKMK pada Laporan Keuangan}

Komite audit berdasarkan Peraturan Otoritas Jasa Komiti audit dapat dikatakan sebagai "komite yang berada di bawah dewan komisaris dan bertugas untuk melakukan penelaahan atas informasi keuangan yang akan dikeluarkan oleh perusahaan termasuk informasi di laporan keuangan, ketaatan perusahaan terhadap peraturan perundang-undangan, dan penelaahan atas pelaksanaan pemeriksaan oleh auditor internal" (Peraturan OJK No 55/POJK.4/2015). Selain itu, EKA merupakan bagian dari CG yang diperkirakan mempengaruhi luasnya pengungkapan kompensasi manajemen kunci di laporan keuangan.

Berdasarkan riset Zhangg et al. (2007) mengatakan bahwa EKA akan berbanding lurus dengan efektifnya pengendalian dalam entitas. Efektinya pengendalian internal perusahaan diharapkan dapat memacu perusahaan untuk patuh pada regulasi, yaitu remunerasi yang berikan kepada dirkesi dan komisaris.

Utama (2006) juga mengatakan komiti audit yang bertugas secara baik akan memacu manajemen perusahaan guna melakukan penyampain terhadap informasi yang material berhubungan dengan perusahaan. Salah satu informasi tersebut adalah kompensasi manajemen kunci.

Adapun tujuan komite audit dibentuk adalah "untuk mengembangkan kualitas pelaporan keuangan, memastikan bahwa direksi membuat keputusan berdasakan kebijakan, praktik dan pengungkapan akuntansi, menelaah ruang lingkup dan hasil dari audit internal dan eksternal dan melakukan pengawasan dalam proses pelaporan keuangan". Riset (Akmyga \& 
Mita 2016; 2015; Fauziah 2018) menemukan bahwa EKA mempunyai pengaruh yang signifikan pada LPKMK.. Hal ini dikarenakan perusahaan yang punya komiti audit dapat bertugas secara baik bisa memacu pihak manejemen untuk dapat menyajikan lebih luas informasi berkaitan dengan LPKMK dalam laporan keuangan.

\section{Pengaruh KA Terhadap LPKMK di Laporan Keuangan}

KA merupakan suatu tingkat kemampuan auditor dalam memahami bisnis klien (Kane \& Velury, 2005). Bassett et, al. (2008) menyatakan bahwa terdapat hubungan yang berbanding lurus antara KA dengan luas informasi keuangan yang diungkapkan oleh perusahaan. Seandainya KA cukup baik suatu perusahaan, maka semakin luas penyajian informasi . Demikian sebaliknya, semakin kurang baik suatu entitas KA, semakin kurang penyampaian informasi oleh sebuah entitas.

KA dapat diukur dengan melihat besar kecilnya ukuran KAP (Kantor Akuntan Publik). Nelson \& Percy (2005) menyebutkan bahwa perusahaan yang diaudit oleh KAP yang berukuran besar, melakukan pengungkapan informasi yang lebih luas di laporan keuangan. Hal ini dikarenakan KAP besar (Big Four) sangat menjaga reputasinya, sehingga KAP akan melakukan proses audit sesuai standar audit yang berlaku.

Studi yang dikerjakan Malak (2016) di Malasyia menunjukkan KA mempunyai hubungan dengan penyampaian remunerasi eksekutif individu di laporan keuangan perusahaan. Hasil tersebut juga konsisten dengan hasil penelitian di Indonesia yang dilakukan oleh Farahmita (2012) Akmyga \& Mita (2015), Fauziah (2018), dan Mayresa 2018) menemukan bahwa kualitas audit berpengaruh secara signifikan dan positif terhadap keluasan dan kelengkapan pengungkapan kompensasi manajemen kunci di laporan keuangan.

\section{Pengaruh KI, KM, EKA, dan KA Terhadap LPKMK di Laporan Keuangan}

Dalam penelitian ini, KI, KM, EKA, dan KA selain diuji secara parsial namun secara simultan juga dilakukan pengujian. Berdasarkan rumusan dan permasalahan yang telah diuraikan sebelumnya, maka skema kerangka pemikiran studi ini diilustrasikan dalam gambar 2.1.

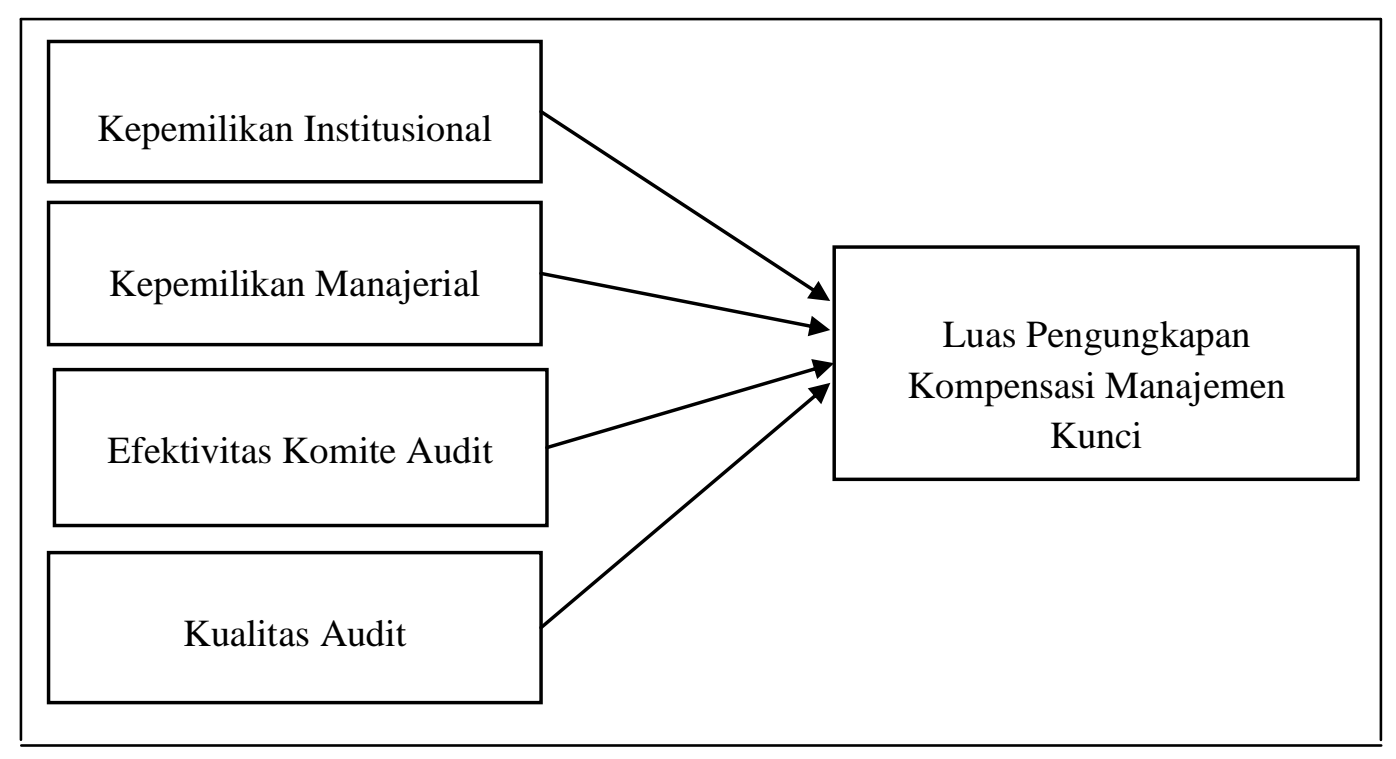

Gambar 2.1 Bagan Kerangka Pemikiran 


\section{Hipotesis}

Pada riset ini peneliti menawarkan beberapa hipotesis yaitu:

H1 :KI, KM, EKA, dan KA secara simultan mempunyai pengaruh bersifat positif pada LPKMK.

$\mathrm{H} 2 \quad$ :KI mempunyai pengaruh dengan sifat positif LPKMK.

H3 :KM mempunyai pengaruh yang bersifat positif pada LPKMK.

H4 :EKA mempunyai pengaruh dengan sifat positif pada LPKMK.

H5 :EKA mempunyai pengaruh dengan sifat positif pada LPKMK.

\section{Metode Penelitian}

\section{Desain Penelitian}

Penelitian ini memiliki sifat studi kausal, karena bertujuan untuk menguji hubungan antar variabel.
Jenis penelitian yang dipilih adalah kuantitatif, dengan menggunakan unit analisis organisasi yaitu perusahaan sektor perdagangan yang terdaftar di BEI periode 2015 s.d. 2017. Oleh karena itu, peneliti menggunakan horizon waktu studi longitudinal dengan data panel.

\section{Populasi dan Sampel Penelitian}

Populasi dalam penelitian ini adalah seluruh perusahaan sektor perdagangan yang terdaftar di BEI untuk tahun penelitian 2015 s.d. 2017. Adapun teknik pengambilan sampel yang digunakan yaitu teknik nonprobability sampling dengan menggunakan purposive sampling., yaitu pemilihan sampel dengan tujuan atau kriteria tertentu yang ditentukan oleh peneliti Adapun kriteria-kriteria perusahaan yang ditentukan oleh peneliti adalah:

Tabel 3.1

\section{Pemilihan Sampel Penelitian}

\begin{tabular}{|l|c|}
\hline Kriteria & \\
\hline Jumlah Populasi & 61 \\
\hline Perusahaan sektor perdagangan yang tidak terdaftar di BEI periode 2015 s.d. 2017. & $(5)$ \\
\hline Perusahaan sektor perdagangan yang tidak menerbitkan laporan keuangan dan laporan tahunan selama periode & $(15)$ \\
2015 s.d. 2017. & \\
\hline Total perusahaan sektor perdagangan yang menjadi sampel penelitian & 41 \\
\hline Total Observasi & $\mathbf{4 1 ~ X ~ 3 = 1 2 3}$ \\
\hline
\end{tabular}

Sumber: Data sekunder yang diolah,IDX (2019).

\section{Teknik Pengumpulan Data}

Data yang digunakan peneliti adalah data sekunder berupa laporan keuangan dan laporan tahunan 2015 s.d. 2017. Data tersebut didapatkan dengan mengunduh dari situs BEI dan situs perusahaan.

\section{Operasionalisasi Varibel \\ Variabel Dependen}

variabel dependen yang akan diteliti adalah LPKMK (luas pengungkapan kompensasi manajemen kunci) dalam laporan keuangan. LPKMK diukur menggunakan pengukuran yang dikembangkan oleh (Farahmita,2012). Adapun skor pengungkapan terbagi lima, yaitu:
1. Diberikan nilai 0 seandainya entitas tidak menyajikan gaji manejemen kunci di laporan keuangan.

2. Diberikan nilai 1 seandaianya entitas hanya menyajikan seluruh gaji tanpa ilustrasi jenis balas jasa.

3. Diberikan nilai 2 seandainya entitas menyajikan seluruh gaji tiap-tiap komisaris dan direktur.

4. Diberikan nilai 3 seandainya entitas menyajikan semua gaju dengan menambah ilustrasi /jenis imbalan.

5. Diberikan nilai 4 jika entitas menyajikan seluruh remunerasi dan menambah perincian subjumlah perjenis gaji.

Skor yang diperoleh kemudian dibagi dengan skor maksimal agar dapat mengetahui nilai LPKMK, 
alhasil skor LPKMK beragam dari 0 - 1. Adapun rumus matematisnya adalah sebagai berikut:

$$
\text { LPKMK }=\frac{\text { Skor Pengungkapan }}{\text { Skor Maksimal }}
$$

\section{Variabel Independen}

Variabel independen yang digunakan dalam penelitian ini yaitu sebagai berikut:

\section{KI (Kepemilikan institusional)}

KI merupakan "kepemilikan saham oleh pihakpihak yang berbentuk institusi seperti yayasan, bank, perusahaan asuransi, dana pensiun, dan perusahaan investasi yang berbentuk PT (Perseoraan Terbatas)" (Tamba, 2011).

$$
\mathrm{KI}=\frac{\begin{array}{l}
\text { Jumlah Saham yang Dimiliki } \\
\text { oleh Pihak Institusi }
\end{array}}{\text { Jumlah Saham yang Beredar }} \text { X 100\% }
$$

\section{KM (Kepemilikan Manajerial)}

KM merupakan "suatu kondisi di mana pihak manajemen merangkap jabatan yaitu sebagai manajemen perusahaan dan sebagai pemegang saham perusahaan" (Musaffa, 2017).

$$
\mathrm{KM}=\frac{\begin{array}{l}
\text { Jumlah Saham yang Dimiliki } \\
\text { Pihak Manajemen }
\end{array}}{\text { Jumlah Saham yang Beredar }}
$$

\section{EKA (Efektivitas Komite Audit)}

EKA merupakan kondisi di mana komite audit yang dibentuk oleh suatu perusahaan dapat berfungsi secara efektif. EKA dihitung memakai checklist EKA dalam (Lampiran 1), diciptkan (Hermawan, 2009).

Cara ukur ini dianggap cocok karena telah memperhatikan macam aspek Checklist memakai 11 indikator dengan nilai 1 akan ditulis jika masuk kategori poor, nilai 2 akan dianggap jika masuk kategori fair, dan nilai 3 dianggap jika masuk jenis good. Nilai dari 11 checklist dalam tiap tiap entitas kemudian dijumlahkan lalu dibagi dengan nilai maksimum. Akibatnya nilai skor akan berada dari nilai 0 hingga 1.

$$
\mathrm{KI}=\frac{\begin{array}{c}
\text { Jumlah Saham yang } \\
\text { Dimiliki oleh Pihak Institusi }
\end{array} \text { Jumlah Saham yang Beredar }}{\text { Juma }} \text { 100\% }
$$

\section{KA (Kualitas Audit)}

KA bisa dikatakan sebagai "suatu tingkat kemampuan auditor dalam memahami bisnis klien" (Kane \& Velury, 2005). KA menguukur berdasarkan besar kecilnya KAP yang mengaudit entitas. Diberikan skor 1 jika seandainya entitas diaudit oleh KAP Big four dan dikasih nilai 0 jika entitas diaudit oleh KAP non Big four. KAP yang termasuk dalam kategori ukuran Big four terdiri dari KAP Purwantono, Suherman, \& Surja yang berafiliasi dengan EY (Ernst and Young International), KAP Tanudireja, Wibisana $\&$ rekan berafiliasi dengan $\mathrm{PwC}$ (Price waterhouse Coopers), KAP Shidharta dan Widjaja berafiliasi dengan KPMG (Klynveld Peat Main Goerdeler), dan KAP Osman, Bing, Satrio, dan rekan berafiliasi dengan Delloitte Touche and Tohmatsu.

\section{Metode Analisis dan Rancangan Pengujian Hipotesis}

Penelitian ini menggunakan analisis regresi linear berganda. Analisis data menggunakan aplikasi SPSS. Adapun model regresi sebagai berikut.

\section{LPKMK $=a+b_{1} K I+b_{2} K M+b_{3} E K A+b_{4} K A+e$}

Keterangan:

$\begin{array}{ll}\text { LPKMK = } & \text { Luas Pengungkapan Kompensasi } \\ & \text { Manajemen Kunci } \\ \mathrm{a} & =\text { Konstanta } \\ \mathrm{b}_{1}-\mathrm{b}_{4} & =\text { Koefisien Regresi } \\ \mathrm{KI} & =\text { Kepemilikan Institusional } \\ \mathrm{KM} & =\text { Kepemilikan Manajerial } \\ \mathrm{EKA} & =\text { Efektivitas Komite Audit } \\ \mathrm{KA} & =\text { Kualitas Audit } \\ \mathrm{e} & =\text { Error }\end{array}$




\section{Hasil Dan Pembahasan}

\section{Uji Asumsi Klasik}

\section{Hasil Uji Normalitas}

Tabel 4.1

Uji Normalitas

\begin{tabular}{|l|l|r|}
\hline \multicolumn{2}{|c|}{ One-Sample Kolmogorov-Smirnov Test } \\
\hline \multicolumn{2}{|c|}{} & Unstandardized Residual \\
\hline N & Mean & 123 \\
\hline \multirow{2}{*}{ Normal Parameters ${ }^{\text {a,b }}$} & Std. Deviation & 0,0000000 \\
\hline \multirow{2}{*}{ Most Extreme Differences } & Absolute & 0,24563405 \\
\cline { 2 - 3 } & Positive & 0,088 \\
\cline { 2 - 3 } & Negative & 0,054 \\
\hline Kolmogorov-Smirnov Z & & $-0,088$ \\
\hline Asymp. Sig. (2-tailed) & & 0,0975 \\
\hline a. Test distribution is Normal. & 0,298 \\
\hline b. Calculated from data. & \\
\hline
\end{tabular}

Sumber: Output SPSS (2019)

Berdasarkan Tabel 4.1 menunjukkan bahwa nilai signifikansi Kolmogorov Smirnov sebesar 0,0975. Hal ini menjelaskan bahwa data penelitian ini terdistribusi secara normal, karena nilai signifikansi Kolmogorov Smirnov sebesar 0,0975 lebih besar dari nilai signifikansi $0,05(5 \%)$.

\section{Uji Multikolinearitas}

Tabel 4.2

Uji Multikolinearitas

\begin{tabular}{|cc|c|c|}
\hline \multicolumn{4}{|c|}{ Coefficients $^{\mathbf{a}}$} \\
\hline \multicolumn{2}{|c|}{ Model } & \multicolumn{2}{c|}{ Collinearity Statistics } \\
\cline { 3 - 4 } & & Tolerance & VIF \\
\hline 1 & KI & 0,898 & 1,113 \\
\hline
\end{tabular}

\section{Uji Heteroskedastisitas}

Tabel 4.3

Uji Heterokedastisitas

\begin{tabular}{|c|c|c|c|c|c|}
\hline \multicolumn{6}{|c|}{ Coefficients $^{\mathrm{a}}$} \\
\hline \multirow{2}{*}{ Model } & \multicolumn{2}{|c|}{ Unstandardized Coefficients } & \multirow{2}{*}{$\begin{array}{c}\text { Standardized Coefficients } \\
\text { beta }\end{array}$} & \multirow{2}{*}{$\mathrm{t}$} & \multirow{2}{*}{ Sign. } \\
\hline & B & Std. Error & & & \\
\hline 1 (Constant) & 0,299 & 0,100 & & 2,997 & 0,003 \\
\hline KI & $-0,108$ & 0,72 & $-0,143$ & $-1,489$ & 0,139 \\
\hline KM & $-0,162$ & 0,243 & $-0,061$ & $-0,664$ & 0,508 \\
\hline EKA & $-0,028$ & 0,094 & $-0,028$ & $-0,294$ & 0,769 \\
\hline KA & 0,004 & 0,025 & 0,014 & 0,147 & 0,883 \\
\hline
\end{tabular}

a. Dependent Variable: abs_res

Sumber: Output SPSS (2019) 
Berdasarkan Tabel 4,3 tersebut menunjukkan bahwa keseluruhan nilai signifikansi variabel independen memperlihatkan jauh lebih besar dari 0,05 atau 5\%. Maka dengan demikian, dapat ditarik simpulan gejala heterokedastisitas tidak terjadi pada model regresi.

\section{Uji Autokorelasi}

\section{Tabel 4.4}

\section{Uji Autokorelasi}

\begin{tabular}{|l|c|c|c|c|c|}
\hline \multicolumn{7}{|c|}{ Model Summary $^{\mathbf{b}}$} \\
\hline \multicolumn{1}{|c|}{ Model } & $\mathrm{R}$ & $\mathrm{R}$ Square & Adjusted R Square & Std. Error of the Estimate & Durbin-Watson \\
\hline 1 & $0,525^{\mathbf{a}}$ & 0,276 & 0,252 & 0,24976 & 2,103 \\
\hline a. Predictors: (Constant), KA, KM, KI, EKA & & & \\
\hline
\end{tabular}

Sumber: Output SPSS (2019)

Mengacu tabel 4.4 menunjukkan nilai DW sebanyak 2,103. Dimana nilai dL sebesar 1,6392 dan nilai dU sebesar 1,7733 , serta nilai $4-\mathrm{dU}$ sebesar 2,227. Oleh sebab itu, Dengan demikian, nilai DW terletak diantara dU dan $4-\mathrm{dU}$, yaitu $1,7733<2,103$ $<2,227$. Sehingga simpulannya yaitu autokorelasi tidak terjadi.

\section{Analisis Regresi Linear Berganda}

Hasil regresi pengaruh tiap-tiap variabel independen terhadap variabel dependen dapat dilihat pada Tabel 4.5.

Tabel 4.5

Uji Signifikansi Parameter Individual (Uji Statistik t)

\begin{tabular}{|c|c|c|c|c|c|}
\hline \multicolumn{6}{|c|}{ Coefficients ${ }^{\mathrm{a}}$} \\
\hline \multirow{2}{*}{ Model } & \multicolumn{2}{|c|}{ Unstandardized Coefficients } & \multirow{2}{*}{$\begin{array}{c}\text { Standardized Coefficients } \\
\text { beta }\end{array}$} & \multirow{2}{*}{$\mathrm{t}$} & \multirow{2}{*}{ Sign. } \\
\hline & $\mathrm{B}$ & Std. Error & & & \\
\hline 1 (Constant) & $-0,059$ & 0,180 & & $-0,328$ & 0,743 \\
\hline KI & 0,401 & 0,131 & 0,254 & 3,071 & 0,003 \\
\hline KM & 0,866 & 0,439 & 0,155 & 1,973 & 0,051 \\
\hline EKA & 0,477 & 0,170 & 0.232 & 2,805 & 0,006 \\
\hline KA & 0,240 & 0,045 & 0,416 & 5,287 & 0,000 \\
\hline
\end{tabular}

a. Dependent Variable: LPKMK

Sumber: Output SPSS (2019)

Berdasarkan Tabel 4.5 tersebut menunjukkan persamaan regresi linear berganda sebagai berikut:

\section{Hasil Pengujian Hipotesis \\ Uji Statistik F}

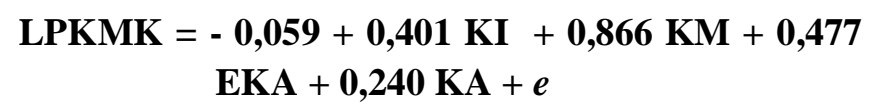

Tabel 4.6

Uji Signifikansi Bersama-sama (Uji Statistik F)

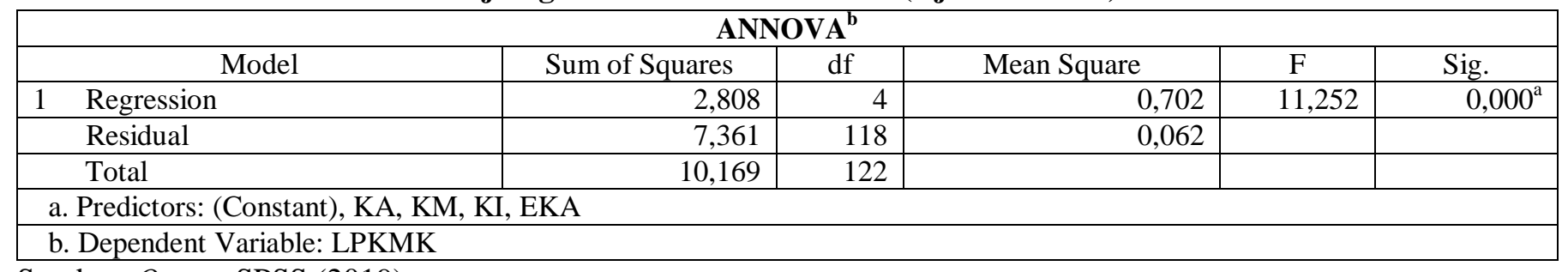

Sumber: Output SPSS (2019) 
Berdasarkan Tabel 4.6 tersebut menunjukkan bahwa nilai signifikansi sebesar 0,000 dimana nilai signifikansi tersebut lebih kecil dari 0,05 (5\%) . Hal ini dapat disimpulkan bahwa hipotesis $\left(\mathrm{H}_{1}\right)$ diterima, sehingga variabel KI, KM, EKA, dan KA terhadap LPKMK laporan keuangan.

\section{Uji Statistik t}

Hasil uji sebagai berikut:

1. Variabel KI diketaui mempunyai nilai $\mathrm{t}$ sebesar 3,071 dan nilai signifikansi sebesar 0,003 lebih kecil dari taraf signifikansi $0,05 \quad(5 \%)$. Mengindikasikan KI mempunyai pengaruh yang signifikan dan bersifat positif pada LPKMK. Akibatnya, $\left(\mathrm{H}_{2}\right)$ diterima.

2. Variabel KM diketahui mempunyai nilai t sekitar 1,973 dan nilai signifikansi sebesar 0,051 lebih besar dari dari taraf signifikansi 0,05 (5\%).
Mengindikasikan KM mempunyai pengaruh yang signifikan dan bersifat positif pada LPKMK. Akibatnya, $\left(\mathrm{H}_{3}\right)$ ditolak.

3. Variabel EKA diketahui mempunyai nilai t sebesar 2,805 dan nilai signifikansi sebesar 0,006 lebih kecil dari taraf signifikansi 0,05 (5\%). Menandakan EKA mempunyai pengaruh yang signifikan serta bersifat positif pada LPKMK. Akibatnya, $\left(\mathrm{H}_{4}\right)$ diterima.

4. Variabel KA diketahui mempunyai nilai t sebesar 5,287 dan nilai signifikansi sebesar 0,000 lebih kecil dari taraf signifikansi 0,05 (5\%). Menunjukkan KA mempunyai pengaruh yang signifikan dan bersifat positif pada LPKMK. Akibatnya, $\left(\mathrm{H}_{5}\right)$ diterima.

\section{Koefisien Determinasi $\left(R^{2}\right)$}

Tabel 4.7

Koefisien Determinasi $\left(\mathbf{R}^{2}\right)$

\begin{tabular}{|l|c|c|c|c|c|}
\hline \multicolumn{7}{|c|}{ Model Summary $^{\mathbf{b}}$} \\
\hline \multicolumn{1}{|c|}{ Model } & $\mathrm{R}$ & $\mathrm{R}$ Square & Adjusted R Square & Std. Error of the Estimate & Durbin-Watson \\
\hline 1 & $0,525^{\mathbf{a}}$ & 0,276 & 0,252 & 0,24976 & 2,103 \\
\hline a. Predictors: (Constant), KA, KM, KI, EKA \\
\hline
\end{tabular}

Sumber: Output SPSS (2019)

Berdasarkan Table 4,7 tersebut menunjukkan nilai koefisien determinasi $\left(\mathrm{R}^{2}\right)$ sebesar 0,276. Nilai mengindikasikan 27,6 \% variasi LPKMK di laporan keuangan dipengaruhi oleh variasi empat variabel independen yaitu; KI, KM, EKA, dan KA., adapun sisanya sebesar 0,624 atau $62,4 \%$ dijelaskan oleh variabel-variabel lain diluar model tersebut.

\section{Pembahasan}

\section{Pengaruh KI, KM, EKA, dan KA pada LPKMK pada Laporan Keuangan}

Berdasarkan hasil pengujian statistik yang dilakukan diperoleh nilai signifikansi 0,000 , dimana nilai signifikansi tersebut lebih kecil dari taraf signifikansi $0,05(5 \%)$. Oleh karenanya dapat ditarik kesimpulan hipotesis $\left(\mathrm{H}_{1}\right)$ diterima, sehingga dapat ditarik simpulan bahwa variabel KI, KM, EKA, dan KA mempunyai pengaruh secara bersama-sama dan sifat posited terhadap LPKMK di laporan keuangan.
Adapun besarnya hubungan itu yaitu $27,6 \%$, nilai ini ditujukan oleh nilai $\mathrm{R}^{\wedge} 2$ sebesar 0,276 , ataupun yang lainnya 0,624 atau $62,4 \%$ dipengaruhi oleh variabel bebas lainnya. Berkenaan dengan hal tersebut, dengan melihat pada KI, KM, dan EKA, dan KA dapat memberikan gambaran bahwa keempat variabel tersebut dapat meningkatkan LPKMK di laporan keuangan entitas sektor perdagangan.

\section{Pengaruh KI pada LPKMK dalam Laporan Keuangan}

Berdasarkan hasil pengujian hipotesis yang dilakukan, diperoleh nilai koefisien regresi variabel KI sebesar 0,401 dan bersifat positif, artinya seandainya terjadi nilai KI sebesar $1 \%$ maka akan meningkatkan LPKMK dalam laporan keuangan sebesar 40,1\% dengan anggapan variabel independen lainnya konstan. Disamping itu, didapatkan nilai signifikansi sebesar 0,003 yang lebih kecil dari taraf signifikansi $0,05(5 \%)$. Semua ini mengindikasikan KI mempunyai 
pengaruh yang signifikan dengan sifat positif pada LPKMK dalam laporan keuangan. Akibatnya, $\left(\mathrm{H}_{2}\right)$ diterima. Oleh karenanya bisa disebutkan jika seandainya terjadi peningkatan nilai KI maka akan semakin meningkatkan LPKMK dalam laporan keuangan perusahaan sektor perdagangan.

KI dapat dikatakan sebagai sejumlah persentase tertentu saham suatu perusahaan dikuasai oleh institusi tertentu. "Adanya kepemilikan institusional pada suatu perusahaan akan mendorong peningkatan pengawasan terhadap kinerja manajemen" (Astasari \& Nugrahanti, 2015). Sehingga dapat mendesak pihak manajemen untuk tidak melakukan tindakan penyelewangan yang dapat menurunkan nilai perusahaan (Tamba, 2011). Salah satu pengungkapan yang dapat didorong dengan adanya KI adalah pengungkapan remunerasi yang diserahkan pada direktur dan komisaris suatu entitasi.

Studi penelitian ini memiliki hasil yang konsisten dengan temuan Chizema (2008) yakni KI mempunyai pengaruh bagi pengungkapan kompensasi direktur individu perusahaan. Hasil yang sama juga diperoleh oleh Mayresa (2018) yang menemukan KI mempunyai pengaruh pada LPKMK dalam laporan keuangan perusahaan.

Namun temuan ini berbeda dengan temuan Kang \& Nanda (2018) yang menemukan bahwa KI asing dan india tidak punya pengaruhbagi penyajian remunerasi eksekutif. Riset Astasari \& Nugrahanti (2015) juga menemukan KI mempunyi pengaruh yang negatif bagi LPKMK. "Hal ini mungkin disebabkan karenan selama ini investor institosional sebagai pemegang mayoritas hanya bertujuan untuk memaksimalkan keuntungan pribadi saya tanpa mempedulikan tanggung jawab perusahaan pada stakeholders" (Astasari \& Nugrahanti, 2015)

\section{Pengaruh KM pada LPKMK di Laporan Keuangan}

Mengacu pada hasil olah data didapatkan nilai koefisien regresi variabel KI sebesar sebesar 0,866 dan bertanda positif, artinya seandainya ada terjadi peningkatan nilai $\mathrm{KM}$ sebesar $1 \%$ maka akan meningkatkan LPKMK dalam laporan keuangan sebesar 86,6\% dengan anggapan variabel independen lainnya konstan. Kondisi ini pada dasarnya mengindikasikan KM mempunyai pengaruh pada LPKMK dalam laporan keuangan. Namun pengaruh yang diberikan tidak signifikan, sesuai dengan hasil olah data yang didapatkan nilai $\mathrm{t}$ sebesar 1,973 dengan tingkat signifikansi sebesar 0,051 yang lebih besar dari dari taraf signifikansi 0,05 (5\%). Menandakan KM tidak mempunyai pengaruh bagi LPKMK dalam laporan keuangan. Dengan demikian, $\left(\mathrm{H}_{3}\right)$ ditolak.

Penolakan hipotesis ini diakibatkan oleh tidak banyak saham perusahaan sektor perdagangan dimiliki oleh pihak manajer. Selain itu, KM yang rendah sehingga tidak memiliki kemampuan untuk memberikan pengaruh yang besar bagi LPKMK di laporan keuangan perusahaan sektor perdagangan.

Temuan ini sejalan dengan temuan Akmyga \& Mita (2015) yakni KM tidak mempunyai pengaruh bagi LPKMK dalam laporan keuangan. Selain itu, Fauziah (2018) juga mendaptkan hasil KM tidak mempengaruhi LPKMK dalam laporan keuangan. Astasari \& Nugrahanti (2015) juga menemukan KM tidak punya pengaruh terhadap LPKMK. Namun temuan ini tidak sejalan temuan Suherman (2018) yang menemukan KM mempunya pengaruh bagi LPKMK dalam laporan keuangan.

\section{Pengaruh EKA pada LPKM di Laporan Keuangan}

Berdasarkan hasil pengujian hipotesis yang Mengacu pada Berdasarkan hasil olah data, didapatkan skor koefisien regresi sebesar 0,477 dan bertanda positif, artinya seandainya terjadi peningkatan nilai EKA sebesar 1\% maka akan meningkatkan LPKMK dalam laporan keuangan sebesar $47,7 \%$ dengan anggapan variabel independen lainnya konstan. Selain itu nilai $\mathrm{t}$ sebesar 2,805 dengan tingkat signifikansi sebesar 0,006 yang lebih kecil dari taraf signifikansi 0,05 (5\%). Mengindikasikan EKA mempunyai pengaruh yang signifikan dengan sifat positif pada LPKM dalam laporan keuangan. Akibatnya, $\left(\mathrm{H}_{4}\right)$ diterima. Sehingga dapat diakatakan jika komite audit bisa bekerja lebih efektif maka akan meningkatkan LPKMK di laporan keuangan perusahaan sektor perdagangan.

Komite audit dapat dikatakan sebagai "komite yang berada di bawah dewan komisaris dan bertugas untuk melakukan penelaahan atas informasi keuangan yang akan dikeluarkan oleh perusahaan termasuk informasi di laporan keuangan, ketaatan perusahaan terhadap peraturan perundang-undangan, dan penelaahan atas pelaksanaan pemeriksaan oleh auditor internal" (Peraturan OJK No 55/POJK.4/2015). 
Zhanng et al. (2007) mengatakan bahwa efektivitas komite akan berbanding lurus dengan efektifnya pengendalian internal perusahaan.

Hasil penelitian ini sejalan dengan hasil riset Akmyga \& Mita (2015) yang menyatakan EKA mempunyi pengaruh yang bersifat positif bagi LPKMK dalam laporan keuangan. Selain itu, Fauziah (2018) juga menemukan bahwa EKA mempunyai pengaruh yang positif bagi LPKMK dalam laporan keuangan. Namun hasil temuan ini tidak sejalan dengan temuan Suherman (2018) yang menyatakan EKA tidak punya pengaruh bagi LPKMK dlam laporan keuangan. Selain itu, Astasari \& Nugrahanti (2015) juga mengatakan ukuran komite audit tidak punya pengaruh signifikan bagi LPKMK dalam laporan keuangan perusahaan. "Hal ini mungkin disebabkan karena keberadaan komite audit disinyalir hanya melakukan penelahan atas informasi keuangan dan akuntansi yang akan dikeluarkan perusahaan tetapi tidak langsung terlibat dalam penyelesaian masalah keuangan yang dihadapi perusahaan“ (Astasari \& Nugrahanti, 2015).

\section{Pengaruh KA pada LPKMK di Laporan Keuangan}

Berdasarkan hasil olah data, didapatkan hasil koefisien regresi sebesar 0,240 dan bertanda positif, mempunyai makna seadnainya terjadi peningkatan nilai KA sebesar $1 \%$ maka akan meningkatkan LPKMK dalam laporan keuangan sebesar 24\% dengan anggapan variabel independen lainnya konstan. Selain itu, diperoleh nilai $\mathrm{t}$ sebesar 5,287 dengan tingkat signifikansi sebesar 0,000 , lebih kecil dari taraf signifikansi 0,05 (5\%). Menandakan KA mempunyai pengaruh bagi LPKMKdalam laporan keuangan. Akibatnya, $\left(\mathrm{H}_{5}\right)$ diterima. Sehingga dapat dikatakan bahwa perusahaan sektor perdagangan yang diaudit oleh KAP Big Four akan meningkatkan LPKMK dalam laporan keuangannya.

KA merupakan "suatu tingkat kemampuan auditor dalam memahami bisnis klien" (Kane \& Velury, 2005). Bassett et, al. (2007) menemukan ada kaitan yang berbanding lurus antara KA dengan luas informasi keuangan yang diungkapkan oleh perusahaan. "perusahaan yang diaudit oleh KAP yang berukuran besar, melakukan pengungkapan informasi yang lebih luas di laporan keuangan" (Nelson \& Percy, 2005). Hal ini disebabkan KAP besar sangat menjaga reputasinya, sehingga KAP akan melakukan proses audit sesuai standar audit yang berlaku.

Temuan riset ini sejalan dengan temuan Malak (2016) di Malasyia yang menyakan KA mempunyai pengaruh bagi pengungkapan remunerasi eksekutif individu. Temuan ini juga sama dengan temuan Farahmita (2012) Akmyga \& Mita (2015), Fauziah (2018), dan Mayresa 2018) yaitu KA mempunyai pengaruh secara signifikan dan positif bagi LPKMK dalam laporan keuangan. Namun temuan ini agak berbeda dengan temuan Suherman (2018) yaitu KA tidak mempunyai pengaruh bagi LPKMK dalam laporan keuangan.

\section{Kesimpulan, Keterbatasan Dan Saran Kesimpulan}

Berdasarkan hasil pembahasan penelitian yang telah dijelaskan sebelumnya, dapat disimpulkan bahwa:

1. KI, KM, EKA, dan KA secara simultan berpengaruh signifikan dan positif bagi LPKMK di laporan keuangan perusahaan sektor perdagangan.

2. KI mempunyai pengaruh signifikan dan positif bagi LPKMK di laporan keuangan perusahaan sektor perdagangan.

3. KM tidak berpengaruh signifikan dan positif terhadap LPKMK dalam laporan keuangan perusahaan sektor perdagangan.

4. EKA mempunyai pengaruh positif bagi LPKMK laporan keuangan perusahaan sektor perdagangan.

5. KA mempunyai pengaruh signifikan dan positif bagi LPKMK dalam laporan keuangan perusahaan sektor perdagangan.

\section{Keterbatasan Penelitian}

Riset ini memiliki keterbatasan yang cocok dijadikan acuan bagi peneliti dikemudian hari selanjutnya supaya hasil penelitian selanjutnya bisa menjadi lebih baik, yaitu:

1. Studi ini hanya meneliti pada perusahaan sektor perdagangan, sehingga hasil yang diperoleh tidak bisa disamaratakan pada seluruh sektor perusahaan yang terdaftar di BEI .

2. Studi ini cuma menggunakan empat variabel independen untuk untuk melihat pengaruh terhadap variabel dependen. Tidak sedikit 
variabel lain yang mungkin dapat mempengaruhi variabel dependen ini

3. Studi ini menggunakan variabel dummy sebagai proksi KA, hal ini mungkin menandakan data dapat memiliki kemungkinan terjadai pelanggaran asumsi klasik.

\section{Saran}

Adapun saran yang bisa peneliti berikan untuk perbaikann kedepannya yaitu:

1. Studi kedepan bisa menggunakan sampel perusahaan sektor pertambangan, supaya dapat mengetahui faktor-faktor yang mempengaruhi LPKMK di laporan keuangan perusahaan sektor pertambangan..

2. Studi kedepan disarankan menambah variabel lain yang mungkin bisa mempengaruhi LPKMK seperti struktur modal

Studi kedepan disarankan bisa memakai ukuran lain bagi variabel KA selain variabel dummy..

\section{Daftar Pustaka}

Akmyga, S. F., \& Mita, A. F. 2015. Pengaruh Sktruktur Corporate Governance dan kualitas Audit Terhadap Luas Pengungkapan Kompensasi Manajemen Kunci dalam laporan keuangan. Jurnal Akuntansi dan Keuangan Indonesia, 12(1): 19-36.

Astasari, K. G. A., \& Nugrahanti, Y. W. 2015. Pengaruh Struktur Kepemilikan, Ukuran Komite Audit, dan Kualitas Audit Terhadap Pengungkapan Kompensasi Manajemen Kunci dalam laporan keuangan. DeReMa Jurnal Manajemen, 10(2): 162-182.

Bhattacharya, \& Spiegel, M. 1991. Insiderr, Outsiders, and Market Breakdowns. The Review of Financilal Studie 1991, 4 (2): 255-282.

Bassett, M., Koh, P., \& Tutticci, I. 2007. The Association Between Employee Stock Option Disclosures and Corporate Governance: Evidence From an Enhanced Disclosure Regime. The British Accounting Review, 39: 303-322.

Chizema, A. 2008. Institutions and Voluntary Compliance: The Disclosure of Individual Executive Pay in Germany, 16(4): 359-374.

Conyon, M. J., \& He, L. 2011. Executive Compensation and Corporate Governance in China. Journal of Corporate Finance, 17(4): 1158-1175.

Donahue, Sean. M. 2008. Executive Compensation: The New Executive Compensation Disclosure
Rules Do Not Result in Complete Disclosure. Fordham Journal of Corporate \& Financial Law. 13(1): 59.

Fauziah, N. 2018. Pengaruh Struktur Corporate Governance dan Kualitas Audit Terhadap Kelengkapan Pengungkapan Kompensasi Manajemen Kunci dalam laporan keuangan. Skripsi. Yogyakarta: Universitas Muhammadiyah.

Financial Accounting Standard Board. 2008. Statement of Financial Accounting Concept No: 2 Qualitative Characteristics of Accounting Information. Amerika Serikat: FASB.

Hermawan, A. A. 2009. Pengaruh Efektivitas Dewan Komisaris dan Komite Audit, Kepemilikan Keluarga, dan Peran Monitoring Bank terhadap Kandungan Informasi Laba. Disertasi, Universitas Indonesia.

Ikatan Akuntan Indonesia. 2018. PSAK No. 7 Tentang Pengungkapan Pihak-Pihak Berelasi. Jakarta: Ikatan Akuntan Indonesia.

Irfana, Muhammad Jauhan \& Muid, D. 2012. Anailsis Pengaruh Debt Default, Kualitas Audit, Opinion Shoping dan Kepemilikan Perusahaan Terhadap Penerimaan Opini Audit Going Concern. Jurnal Akuntansi, 1: 1-25.

Jensen, C., \& Meckling, H. 1976. Theory of The Firm: Managerial Behavior, Agency Costs And Ownership Struckture. Journal of Financial Economics, 3 (4): 305-360.

Kane, G. D., \& Velury, U. 2005. The Impact of Managerial Ownership on The Likelihood of Provision of High Quality Auditing Services. Review Accounting Finance, 4 (2): 86-106.

Kang, Sing, \& Nanda, Payal. 2018. What Determines the disclosure of Managerial Remuneration in Financial Reporting and Accounting. Journal of Financial Reporting and Accounting. Vol 1 (2) $1-35$.

Mayresa, fransiska Dona. 2018. Pengaruh Kepemilikan Saham Institusional, Kualitas Audit, Frekuensi Pertemuan Komite Audit Dan Komite Remunerasi Terhadap Luas Pengungkapan Kompensasi Manajemen Kunci dalam laporan keuangan . Skripsi. Semarang: Universitas Katolik Soegijapranata.

Malak, S.S.D.A. 2015. The determinants of disclosure of individual exec utive director 's remuneration: A Malaysian perspective. Procedia - Social and Behavioral Sciences, 172: 666-673.

Morck, R., \& Yeung, B. 2003. Agency Problems in Large Businees Groups. Entrepreneurship Theory and Practice, 27: 367-382.

Musaffa, A. D. 2017. Pengaruh Tata Kelola 
Perusahaan Dan Struktur Kepemilikan Terhadap Tingkat Kepatuhan Mandatory Disclosure. Skripsi. Yogyakarta: Universitas Negeri Yogyarakarta.

Nelson, J., \& Percy, M. 2005. The Transparancy of Executive Stock Option Disclosures In Australian Annual Reports, School of Accounting Queensland University of Technology, 4 (2): 1-41.

Na'im, Ainun \& Rakhman, Fu'ad. 2000. Analisis Hubungan antara Kelengkapan Pengungkapan Laporan Keuangan dengan Struktur Modal dan Tipe Kepemilikan Perusahaan. Jurnal Ekonomi dan Bisnis Indonesia.

Otoritas Jasa keuangan. 2015. Peraturan Otoritas Jasa Keuangan Nomor 55 tentang Pembentukan dan Pedoman Pelaksanaan Kerja Komite Audit. Jakarta: Otoritas Jasa Keuangan.

Pujiningsih, A. I. 2011. Pengaruh Struktur Kepemilikan, Praktik Corporate Governance Dan Kompensasai Bonus Terhadap Manajemen Laba. Skripsi. Semarang: Universitas Diponegoro.

Purwandari, A., \& Purwanto, A. 2012. Pengaruh Profitabilitas, Leverage, Struktur Kepemilikan dan Status Perusahaan Terhadap Pengungkapan Laporan Keuangan Pada perusahaan Manufaktur di Indonesia. Diponegoro Journal of Accounting, 1 (2): 1-10.

Tamba, E. G. H. 2011. Pengaruh Struktur Kepemilikan Terhadap Pengungkapan Tanggung Jawab Sosial Perusahaan. Skripsi. Semarang: Universitas Diponegoro.

Setyajati, Diana Kusmayanti. 2015. Kepatuhan Pengungkapan Informasi Kompensasi Manajemen Kunci Perusahaan Manufaktur Di Indonesia. Skripsi. Yogyakarta: Universitas Gajah Mada.

Siregar, S. V., \& Utama, S. 2008. Type of earnings management and the effect of ownership structure, firm size, and corporate-governance practices: Evidence from Indonesia. International Journal of Accounting, 43 (1): 127.

Suherman, Monica. 2018. Pengaruh Tata Kelola Perusahaan, Kualitas Audit, Leverage, dan Profitabilitas Terhadap Luas Pengungkapan Kompensasi Manajemen Kunci dalam laporan keuangan. Skripsi. Semarang: Universitas Katolik Soegijapranata.

Utama, M. 2004. Komite Audit, Good Corporate Governance dan Pengungkapan Informasi. Jurnal Akuntansi Dan Keuangan Indonesia, 1: 61-79.
Zhang, Y., Zhou, J., \& Zhou, N. 2007. Audit Committee Quality, Auditor Independence, and Internal Control Weaknesses. Journal of Accounting and Public Policy, 26 (3): 300-327. 